\title{
Status and Prospects of Large Cardamom Cultivation in India
}

\author{
Shweta Sharma* and Viveka Katoch
}

Dept. of Vegetable Science and Floriculture, CSKHPKV, Palampur, Himachal Pradesh (176 062), India

\author{
Corresponding Author \\ Shweta Sharma \\ e-mail: shwetasharma15123@gmail.com
}

\author{
Article History \\ Article ID: IJEP0295 \\ Received in $16^{\text {th }}$ March, 2019 \\ Received in revised form 03 ${ }^{\text {rd }}$ May, 2019 \\ Accepted in final form 26 ${ }^{\text {th }}$ May, 2019
}

\begin{abstract}
Large or black cardamom (Amomum subulatum Roxb.) belongs to family Zingibereaceae and order Scitaminae is one of the important cash crops cultivated largely in the eastern Himalayan region viz., Nepal, Bhutan and Indian states comprising of Sikkim, Uttaranchal, Darjeeling district of West Bengal and recently popularized in North Eastern states. However, during the last decade there has been decline in area and productivity under large cardamom due to multiple factors, it has drastically affected the livelihood of the rural- farming community. Earnest steps should be taken to sustain the livelihood of large cardamom growers. This review addresses the major challenges faced by the large cardamom growers and suggestions or means to restore/enhance the area and productivity; thereby to protect and promote the livelihoods of peasantry. Integrated management with respect to agronomic practices, plant protection measures and post harvest handling approaches have been suggested to resynergise the large cardamom production in the traditional growing areas.
\end{abstract}

Keywords: Large cardamom, diseases, pollination, post harvest, management

\section{Introduction}

Large cardamom (Amomum subulatum Roxb.) commonly known as 'bada elaichi' is one of the world's most ancient spices, belongs to the family Zingiberaceae and is high value low volume crop (Bhutia et al. 2018). Large cardamom is an important spice with a powerful flavoring agent having a distinctive smoky flavour. It is mainly cultivated in the sub-Himalayan region of the north-eastern Indian states, Nepal and Bhutan. It has been recorded that the cultivation has also spread to northern part of Uttar Pradesh (Ngadong and Longkumar, 2017). In Sikkim, large cardamom is known as "alainchii" and is believed to be one of the oldest known spices (Singh and Pothula, 2013). This crop is indigenous to the eastern Himalayan region probably of Nepal and hence also known synonymously as Nepal cardamom (Aryal et al., 2018). In India, the state of Sikkim from North East produces $85 \%$ of total production in the country (Mandal et al., 2018). Large cardamom is also extensively grown in the Darjeeling district of West Bengal. The unique agro- climatic conditions of Sikkim and Darjeeling hills favour these areas to be the major producer of large cardamom in the world (Ghosh et al., 2016). It is often referred as currency crop (Deka et al., 2016). Cardamom play a vital role in the livelihood and food security for farming communities, it is the only source of cash income. Cultivation of this crop has spread to North-Eastern Indian states including Nagaland, Arunachal, Mizoram, Meghalaya and Manipur and to the central Indian Himalayan state of Uttarakhand.

\section{Importance}

Beside being a spice, large cardamom is rich in nutrition and also has medicinal properties. It is a good source of minerals like potassium, calcium, and magnesium. Potassium is an important component of cell that helps to control heart rate and blood pressure. One hundred gram pods contain 1,119 mg of this electrolyte. Copper is required in the production of red blood cells (Yadav et al., 2018). It contains 2-3\% essential oil and has a pleasant aromatic odour. Apart from aroma, it also has high medicinal value. It is also reported that seeds of large cardamom are used as preventive as well as curative measure for throat troubles, lungs congestion, eyelids inflammation, digestive disorders and in pulmonary tuberculosis treatment. Chewing black cardamom seeds helps to cure loss of appetite. Black cardamom is also used as a carminative and stimulant. It can heal respiratory problems like asthma. Black Cardamom seeds have anti-inflammatory properties and they help in the reduction of muscle spasms. Additionally, capsules are rich in many vital vitamins, such as riboflavin, niacin, vitamin-C that is essential for optimum health (Sarkar et al., 2017). It is also used in infection of teeth and gums, as a medicine of stomach disorder and malaria and also used during the antidote manufacture of snake or scorpion venom (Belbase 
et al., 2018).

\section{Climate}

Large Cardamom (Amomum subulatum Roxb.) is mainly grown in the sub-Himalayan region of Nepal, India and Bhutan in such slope lands where the temperature ranges from $5 \circ \mathrm{C}$ to 30 으 with an annual rainfall between 1,500 to $2,500 \mathrm{~mm}$, plants remain dormant during winters and it can withstand up to $2^{\circ} \mathrm{C}$ but the plant is susceptible to frost injury (Paudel et al., 2018, Bhattarai, 2016). It is cultivated in an altitude range of 700-2000m above sea level. It thrives well in the shady, moist and sloppy lands where the cultivation of the other crops is virtually impossible (Aryal et al., 2018). Large cardamom is a seophyte, requires $30-50 \%$ shade. Therefore, crop is grown under the trees utis (Alnus nepalensis), chillone (Schima wallichii), asare (Viburnum cordifolia), nevaro (Ficus spp) and this system is called large cardamom based agroforestry system. It is an ecologically sustainable system.

The area under large cardamom is continuously declining over years. A combination of several factors had almost wiped out large cardamom cultivation. The progressive shift of reliance from traditional commodities to crop diversification and adoption of new income means in other professions is causing serious setback to cardamom farming in the traditional growing area.

\subsection{Factors affecting large cardamom production}

-Diseases and insect- pests incidence,

- Lack of research and development activities and scientific backup in terms of improved varieties,

- Presence of old and senile plantations,

- Lack of techniques for replantation,

- Lack of quality planting materials,

-Pollination and post harvest problems,

- Impediments in gap filling of older plantation,

- Climate change,

- Soil erosion,

-Improper infrastructure,

-Drought during winter,

-Preference of government job among youth,

- Lack of migratory labour,

- Lack of proper management, etc.

Among insect pests; Stem borer (Glyphipterix spp.), shoot fly (Merochlotops dimorphus), leaf eating caterpillar (Artona chorista) and white grub (Holotrichia spp.) are considered as major pests of large cardamom. Since 2014, large cardamom has been found to be infested with tea mosquito bug (Helopeltis theivora) and mealy bug (Paraputo theaecola) in Sikkim. They are going to be major threat for cardamom production in coming years, if not checked properly (Kalita et al., 2016).

In recent years, farmers are facing reduction in yield due to viral diseases like Chirke and Furkey and poor soil conditions.
The Rural Livelihoods and Climate Change Adaptation in the Himalayas (Himalica) pilot scheme is working in partnership with the Environment Conservation and Development Forum (ECDF) to address the problem of declining large cardamom. The main impediment during field surveys in farmers' field were; lack of management practices for in situ soil moisture conservation, lack of knowledge of planting area (some farms cardamom was planted mostly on outward slopped terraces), decreasing water availability. Maintenance and cleaning in the existing ponds and construction of new ponds will definitely improve the ground water availability and soil moisture retention. In the survey it was found that there was lack of disease- free sapling and problem of marketing in 2007 and lack of government support i.e. technical help in large cardamom farming in 2014. But the problem of marketing was not recorded in 2014. It was due to rapid extension in transportation network (Bhatarai, 2016).

Occurrence of leaf blight disease has become the major issue to the large cardamom growers and viral diseases; chirkey and furkey has become common phenomena in most of the fields. Sarkar et al. (2017) reported that the disease spread is more due to the farmers' ignorance and lack of control mechanism. Low market price due to poor processing and lack of quality planting material is the major obstacle being faced by the farmers of Darjeeling. Farmers of this region use traditional kild called as bhatti to dry the capsule which turn the colour of capsule into black or dark brown. Uneven and excessive burning of the capsule results into loss of aroma and poor appearance.

Insect pests like leaf caterpillar (Artona chorista), stem borer (Glyphipterix sp.), white grubs (Anomala sp.) and aphids are some other limiting factors. Aphids are considered rather more harmful than others as they act as vector of viral diseases viz., Chirke and Foorkey. The spread of fungal disease Colletotrichum blight and viral diseases Chirke and Foorkey since have drastically reduced the area and production of large cardamom in Sikkim.

Large cardamom is bisexual and cross- pollinated crop due to its heterostylic (pin-type) nature of flowers. Bumble bees (Bombus braviceps and B. haemorrhoidalis), honey bee (Apis cerena), fruit fly (Bactocera sp.) and skipper (Udaspes folus) were found to be the insect visitors of large cardamom. However, effective pollination has been reported to be carried out by bumble bees only while others are just pollen robbers. Data on pollination efficiency revealed that one visit of bumble bee resulted in $74.84 \%$ of pollination and increased with four visits up to $100 \%$. Pollination efficiency of honey bees was recorded $8.41 \%$ even after five visits. Highly specific mode of pollination makes the crop highly vulnerable due to lower pollinator density (Pollination syndrome). Knowledgebase on pollination aspects is very low among the farmers i.e. only $30-40 \%$ of rural population is aware about the pollination process (Negi et al., 2018). 
According to information revealed by farmers in West Sikkim in a survey, it was found that yield of large cardamom is on rise. Traditional wisdom, scientific farming and improved irrigation practices has led to increase in yield. Farmers are growing 'Seremna' variety of large cardamom which was discovered in 1985-86 by a farmer from the Sukram Limboo region of west Sikkim. Most of the farmers used to grow paddy and corn traditionally, but a couple of years ago, farmers started to grow 'Seremna' variety on virgin, fertile soil which was never been under cardamom before. This variety is grown for short life cycle, bigger-sized thin capsules which are easy to cure and yield up to for four years which allows farmers to follow cultural practices like crop rotation for two years before replanting the variety, Seremna. Farmers can grow legumes and fruits along with large cardamom. Glance at literature revealed that one of the reasons behind decreased production of the large cardamom in Sikkim is monoculture of large cardamom on the same land for several decades. To deal with erratic rainfall, farmers are using decentralised systems of irrigation and in several villages, farmers have also dug tank to harvest rainwater. Farmers are using mulches (dry leaves or grass) and cow dung applied at the base of the plant to maintain soil moisture and fertility. Farmers are following the traditional practice of burning the stubble to keep the plantations healthy and disease free (https://www. downtoearth.org.in).

\section{Management Strategies}

Large cardamom growers are mainly using traditional methods without much use of recommended package of practices. The following suggestions are recommended to address the constraints faced by the farmers.

i. Training facilities should be provided to the growers for scientific cultivation of large cardamom by the government.

ii. Research programme to identify the improved cultivar, disease free variety, improved planting material, disease control mechanism etc and extension pragrammes to provide knowledge to the farmers on pollination aspect.

iii. Replantation scheme should be provided for healthy planting materials as most of the plantation are old.

iv. Establishment of water harvesting structure can ensure the water availability for irrigation throughout the year and to maintain soil moisture.

v. Initiatives has been taken up by the government to provide subsidy to farmers under different schemes for implementing rainwater harvesting system. Therefore, farmers should take the advantage of those schemes.

vi. Weather smart practices should be practiced such as selecting crop varieties based on weather trends, delayed harvesting when rainfall is predicted and use of mulch used to protect the bases of bushes from snow.

vii. Crop insurance should be provided in case of hailstorm, drought, landslide and other climatic risk.

viii. Mechanization of large cardamom cultivation and post harvest operation

ix. Farmers should be trained in post harvest handling of the produce to avoid post-harvest losses.

$x$. Bhattis or improved dryers should be constructed in the villages to maintain flavor which is lost during drying over the fire.

xi. Broadcasting of market information in radios and television is an essential step in raising awareness about the up to date market information amongst the growers.

xii. Better transportation facilities.

xiii. Establishing market linkage through cardamom growers association

\section{References}

Aryal, M.R., Paude, N., Ranjit, M., 2018. Elimination of chhirkey and foorkey viruses from meristem culture of large Cardamom (Amomum subulatum Roxb.). European Online Journal of Natural and Social Sciences 7(2), 424-443.

Belbase, S., Paudel, J., Bhusal, R., Gautam, S., Aryal, A., Kumar, S., 2018. Fungal diseases of large cardamom (Amomum subulatum Roxb.) and Its Integrated Management. International Journal of Current Microbiology and Applied Sciences 7(03), 3316-3321.

Bhattarai, T., 2016. Efficacies and impediments in large cardamom farming in Ilam, Nepal. Economic Journal of Development Issues 21\&22, 1-2.

Bhutia, P.H., Sharangi, A.B., Lepcha, R., Yonzone, R., 2018. Post-harvest and value chain management of large cardamom in hills and uplands. International Journal of Chemical Studies 6(1), 505-511.

Deka, T.N., Gudade, B.A., Saju, K.A., Bora, S.S., 2016. Insect and mammalian pests of large cardamom (Amomum subulatum Roxburgh) in Sikkim Himalaya. Vegetos 29, 3.

Ghosh, A., Das, A., Lepcha, R., Mandal. B., 2016. Identification, distribution and temporal occurrence of aphids infesting large cardamom and their efficiency in transmitting large cardamom viruses in northeastern sub-Himalayan region. Australasian Plant Pathology 45, 533-536.

https://www.downtoearth.org.in/news/climate-change/riseafter-the-fall-61505

Kalita, H., Avasthe, R.K., Gopi, R., Yadav, A., Singh, M., 2016. Tea mosquito bug (Helopeltis theivora) and mealy bug (Paraputo theaecola) - new threats to large cardamom. Current Science 110(8), 1390-1391.

Mandal, S., Tanna, H.R., Nath, A., Singh, R.K., Kumar, A., 2018. Development of low cost portable biomass fired dryer for cardamom drying in hilly areas. Journal of Environmental Biology 39, 1021-1026.

Negi, B.K., Joshi, R.K., Pandey, A., 2018. Status of large 
cardamom (Amomum subulatum roxb.) Farming systems in the changing scenario of modern economics of Sikkim, Himalaya. Global Journal of Bioscience and Biotechnology 7, 189-199.

Ngadong, A., Longkumer, J., 2018. Knowledge and adoption level of large cardamom cultivators of Anjaw district, Arunachal Pradesh. Indian Research Journal of Extension Education 18, 96-100.

Paudel, J., Belbase, S., Gautam, S., Bhusal, R., Kumar, S., 2018. The effect of viral diseases of large cardamom (Amomum subulatum Roxb.) on production and their management. International Journal of Current Microbiology and
Applied Sciences 7(03), 855-860.

Sarkar, S., Gurung, N., Nayak, D., Meena, R., Singh, B., 2017. Large cardamom cultivation-a review. Journal of Agricultural Engineering and Food Technology 4(1), 78-81.

Singh, A.I., Pothula, A.K.., 2013. Postharvest processing of large cardamom in the Eastern Himalaya. Mountain Research and Development 33(4), 453-462.

Yadav, H., Jairath, M.H., Chaturvedi T., 2018. Value chain of organic large cardamom of Sikkim. Journal of Hill Agriculture 9(1), 1-6. 